\title{
ANTHROPOGENIC RELIEF TRANSFORMATION OF LAST GLACIAL AREA: CASE STUDY AT RYCHNOWO V (N POLAND)
}

DOI: http://dx.doi.org/10.18509/GBP.2019.01

UDC: 551.793:902.2(438)

\author{
Tomasz Kalicki ${ }^{1}$ \\ Mariusz Chrabąszcz ${ }^{2}$ \\ Igor Maciszewski $^{3}$ \\ Pawel Przepióra ${ }^{1}$ \\ ${ }^{1}$ Institute of Geography, Jan Kochanowski University in Kielce, Poland \\ ${ }^{2}$ Student Science Club of Geomorphologists „Złoty Bażant”, Jan Kochanowski University in \\ Kielce, Poland \\ ${ }^{3}$ ASINUS Igor Maciszewski, Poland
}

\begin{abstract}
Abstract. The results of geoarchaeological and archaeological research at the Rychnowo $\mathrm{V}$ site are presented. The archaeological site is located on the moraine plateau between two subglacial tunnel valleys currently drained by the upper Drwęca and Grabiczek Rivers. Relief of the moraine plateau is varied by hollows on post-glacial depressions of varying size and degree of filling. These lakes were formed in the Late Glacial and were filled in the Holocene by organic and clastic deposits. At the archaeological site, several settlement phases have been identified related to the Lusatian (main phase) and Wielbark cultures, Early and Late Medieval and Modern periods. Not found in the site permanent or long-term settlement. The site should be considered as group of rather short-lived camps. The most numerous traces of Lusatian culture are not a single phase, but rather multiple returns to the same area at short intervals (the homogeneous ceramics). The activity of the people of Lusatian culture (connected not with cultivation but grazing) at the beginning of the Subatlantic led to slope erosion and soil fossilization in endorheic depression.
\end{abstract}

Keywords: geoarchaeology, Drwęca River basin, Lusatian culture, soil erosion, colluvia

\section{LOCATION}

The study area is located in northern Polnad in the south-western part of Warmia and Mazury voivodship in Ostróda County in Chełmno-Dobrzyń Lake District in the Lubawa Garb mezoregion (Fig. 1). During the last glaciation this elevation separated the Vistula and Mazurian lobe of ice sheet. Relief of the area is formed by wavy till plains cut by tunnel valleys and sandurs, whose surface is varied by hollows left by dead ice [1][2][3].

\section{METHODS AND AIM OF STUDY}

The Rychnowo V site are discovered in 2015 during archaeological supervision conducted by M.Sc. A. Smoliński as part of modernization national road No. 7. Rescue archaeological research were implemented in the period II-VI 2016 commissioned General Directorate of National Roads and Motorways, Branch in Olsztyn, while geoarchaeological in the period from IV to V 2016 [4][5][6]. Geoarcheological research included geomorphological and Quaternary deposits of the site and neighbouring area. Profiles and drilling were made, from which samples were taken for laboratory analysis. 
The grain size analyzes of sediments were made in the Scientific and Educational Laboratories of the Institute of Geography Jan Kochanowski Universitety in Kielce. For these analysis a set of sieves (DIN ISO 3310/1) and Retsch-Rahmen screens were used.

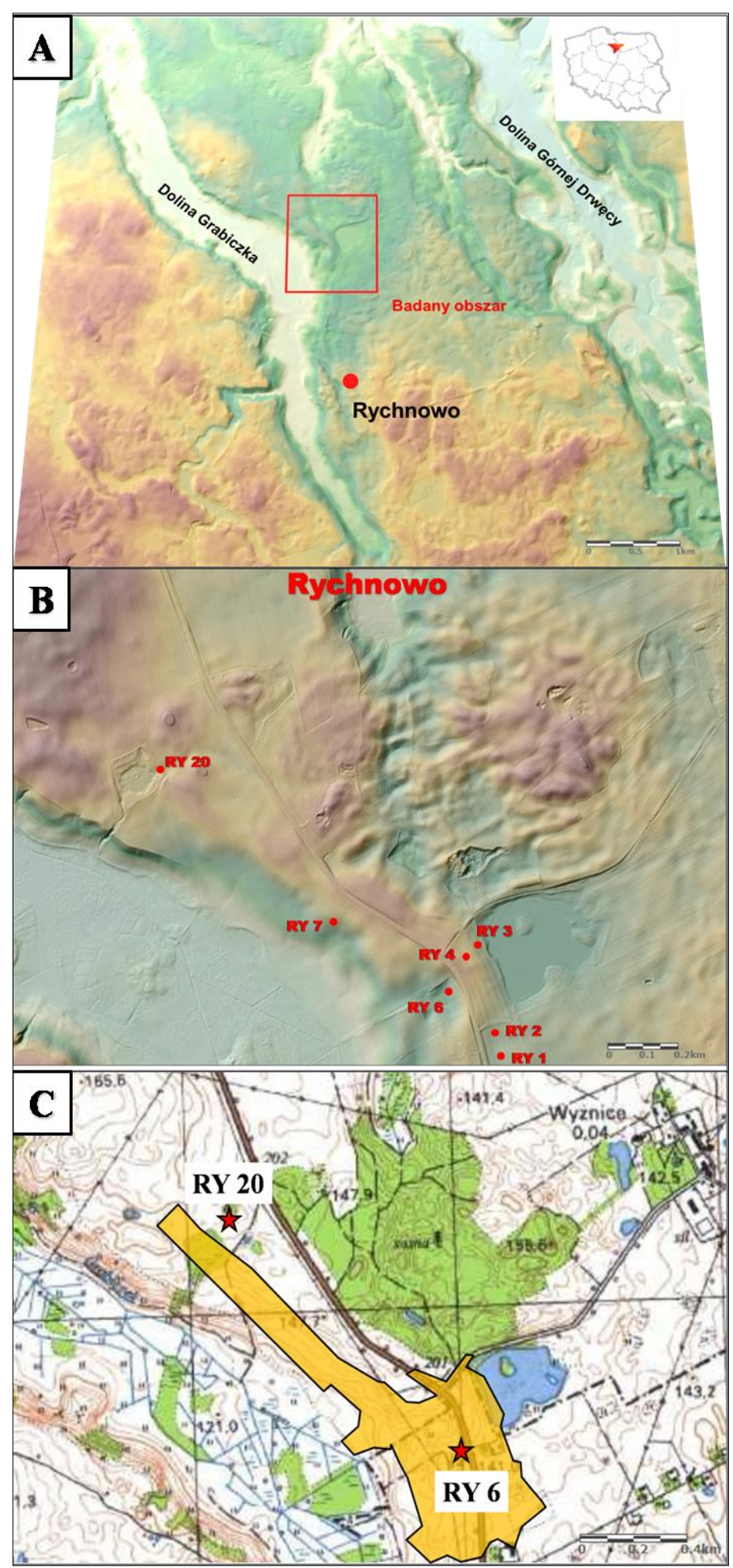

Figure 1. Location of the studied area between river valleys of upper Drwęca and Grabiczek (A) digital elevation model (DEM) of the Rychnowo site with location of studied geological profiles (B) and range of the Rychnowo $\mathrm{V}$ archaeological site on the topographic map with marked geological profiles dated by radiocarbon method $(\mathrm{C})$ 


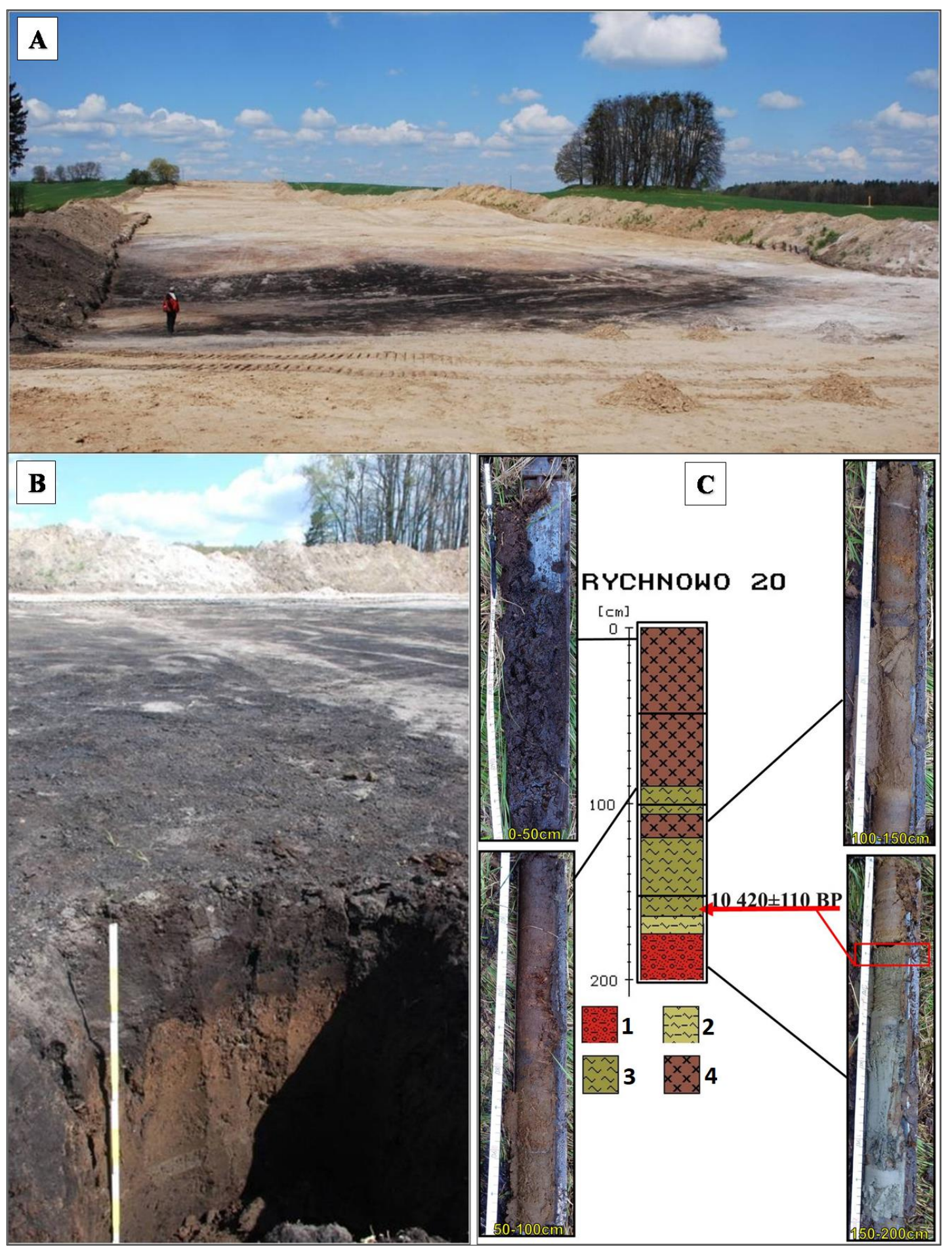

Figure 2. Peaty depression in the place of filled the Young Pleniglacial-Late Glacial glacial pond with the Rychnowo RY 8/20 profile A. general view; B. Rychnowo RY 8 profile: peats $(0-30 \mathrm{~cm})$ lying on gyttja $(30-100 \mathrm{~cm})$; C. Sediments of RY 20 drilling within glacial pond - lithology and radiocarbon dating; 1 tills with single gravels, 2 - gyttja silts, 3 - coarse detritus gyttja, 4 - peats

The results are presented in graphical form in the GRANULOM program, and FolkWard's grain size distribution parameters: $\mathrm{Mz}$ - mean size, $\delta \mathrm{I}$ - standard deviation, SkI skewness, $\mathrm{KG}$ - kurtosis were calculated for all samples [7]. Standard radiocarbon dating were made in ${ }^{14} \mathrm{C}$ Dating Laboratory in Skala. 
The work was also focused on recognition of age and change of sculpture caused by the activity of a prehistoric man. It was possible with a large-scale archaeological excavation, which allowed for a very good recognition of changes in settlement. This case study fits into the problem of environmental changes, including relief, in the areas of the majority of young people covered by the so-called forest zone in archaeological divisions [8][9][10][11].

The examined area is located between two parallel tunnel valleys of the NNWSSE direction. Those tunnel valleys are drained y the upper Drwęca River with its tributary Grabiczek river. Near these two tunnel valleys are preserved small fragments of outwash plains. The site is located on the wavy till plain (moralne upland) elevated about 134-140 $\mathrm{m}$ a.s.l. near the edge of it, which falls into the very distinct in the relief Grabiczek tunnel Valley (Fig. 1). The height of flat valley bottom is 116-117 $\mathrm{m}$ a.s.l., while on its slopes locally in the NW part of the site are preserved narrow valley outwash plains. Directly northward of the site occurs forested moralne hill with a very varied relief and culmination of $155 \mathrm{~m}$ a.s.l. They were formed during one of the phases of the Vistulian ice sheet recession around $17 \mathrm{ka} \mathrm{BP}$, so before the Pomeranian chase (16.2 ka BP), whose stadial recessional moraines are located further to the north. Height differences of relief around the site are more than $40 \mathrm{~m}$. In the upland area there are marked circular depressions, the largest of which is filled by Wyżnice Lake. In smaller of them a melting of dead ice began at the end of the Younger Dryas, as indicated by the radiocarbon dating of $10420 \pm 110$ BP (MKL-3134) $10694-9900$ cal BC from the bottom of organic sediment filling one of them (RY 8/20 profile) (Fig. 2).

Recently remains of glacial kettles (potholes) are swamps and peatbogs. In the middle of the site on the slope of endorheic depression, was found a buried soil covered with deluvia (RY 6 profile). Its fossilization took place about 2850 \pm 60 BP (MKL-3273) 1210-853 cal BC (Fig. 3)which shows the radiocarbon dating from its top. During the archaeological rescue research1 of the site (about 1500 ars) several settlement phases were found: Lusatian culture from Early Iron Age (727 objects, 2470 pottery fragments), Wielbark culture from Roman period (45 objects, 200 pottery fragments), Early Medieval from 1112 th c. ( 4 objects, 11 pottery fragments), Late Medieval ( 28 objects, 91 pottery fragments) and Modern time (33 objects, 88 pottery fragments) (Fig. 4). 


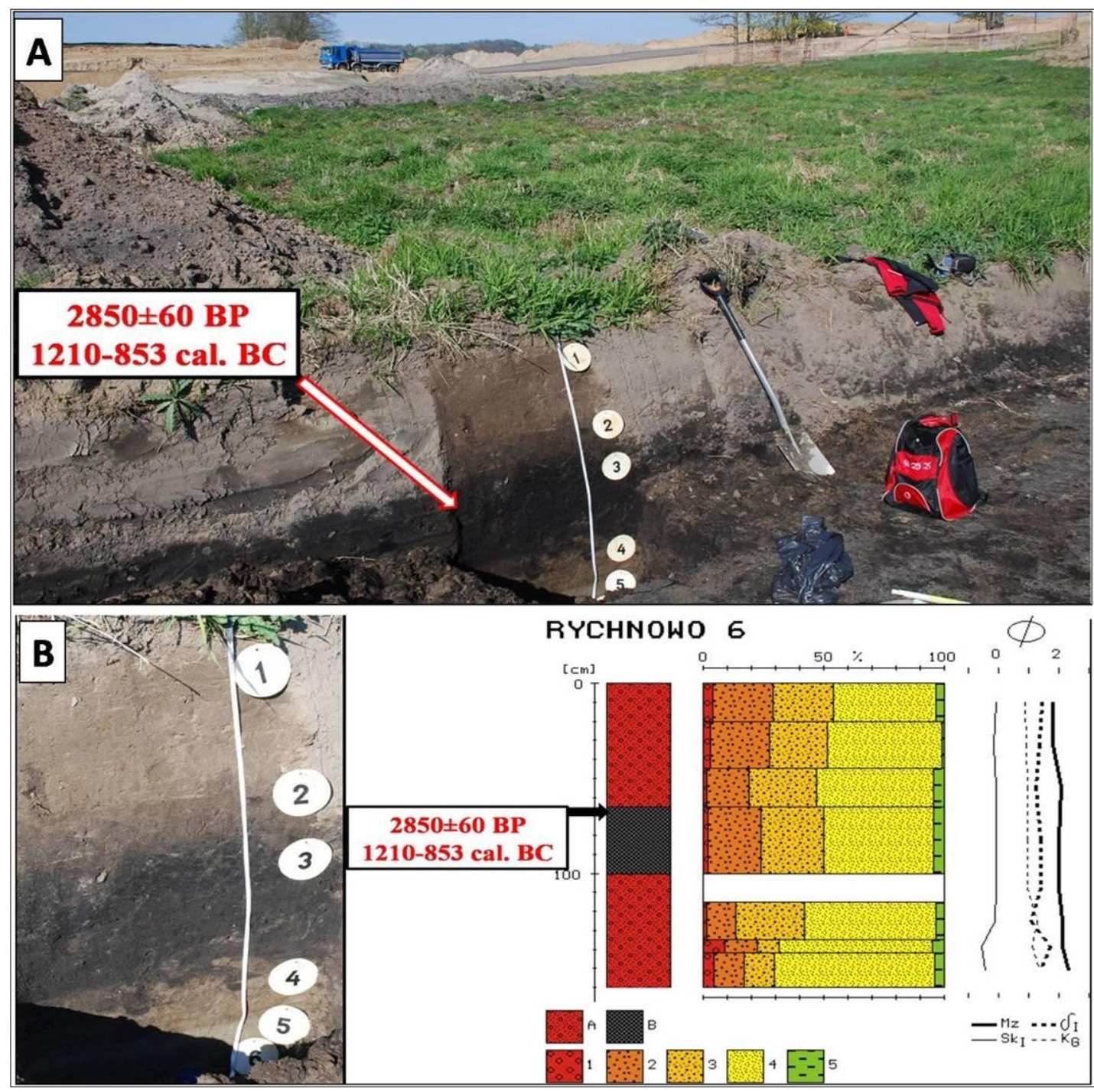

Figure 3. Boggy bottom of the former glacial pond with geological profile of Rychnowo RY 6 with buried soil (layer 3)covered with colluvia (layers 1-2) (A) and grain size and Folk-Ward's distribution parameters (B)

Lithology: A - sands with gravels; B - buried soil; fractions: 1 - gravels (below $-1 \varphi)$; 2 - coarse sands ($1-1 \varphi), 3$ - medium, sands $(1-2 \varphi), 4$ - fine sands $(2-4 \varphi), 5$ - silts and clays (above $4 \varphi$ ); Folk-Ward distribution parameters: $\mathrm{Mz}-$ mean size, $\delta_{\mathrm{I}}-$ standard deviation, $\mathrm{Sk}_{\mathrm{I}}-$ skewness, $\mathrm{K}_{\mathrm{G}}-$ kurtosis 


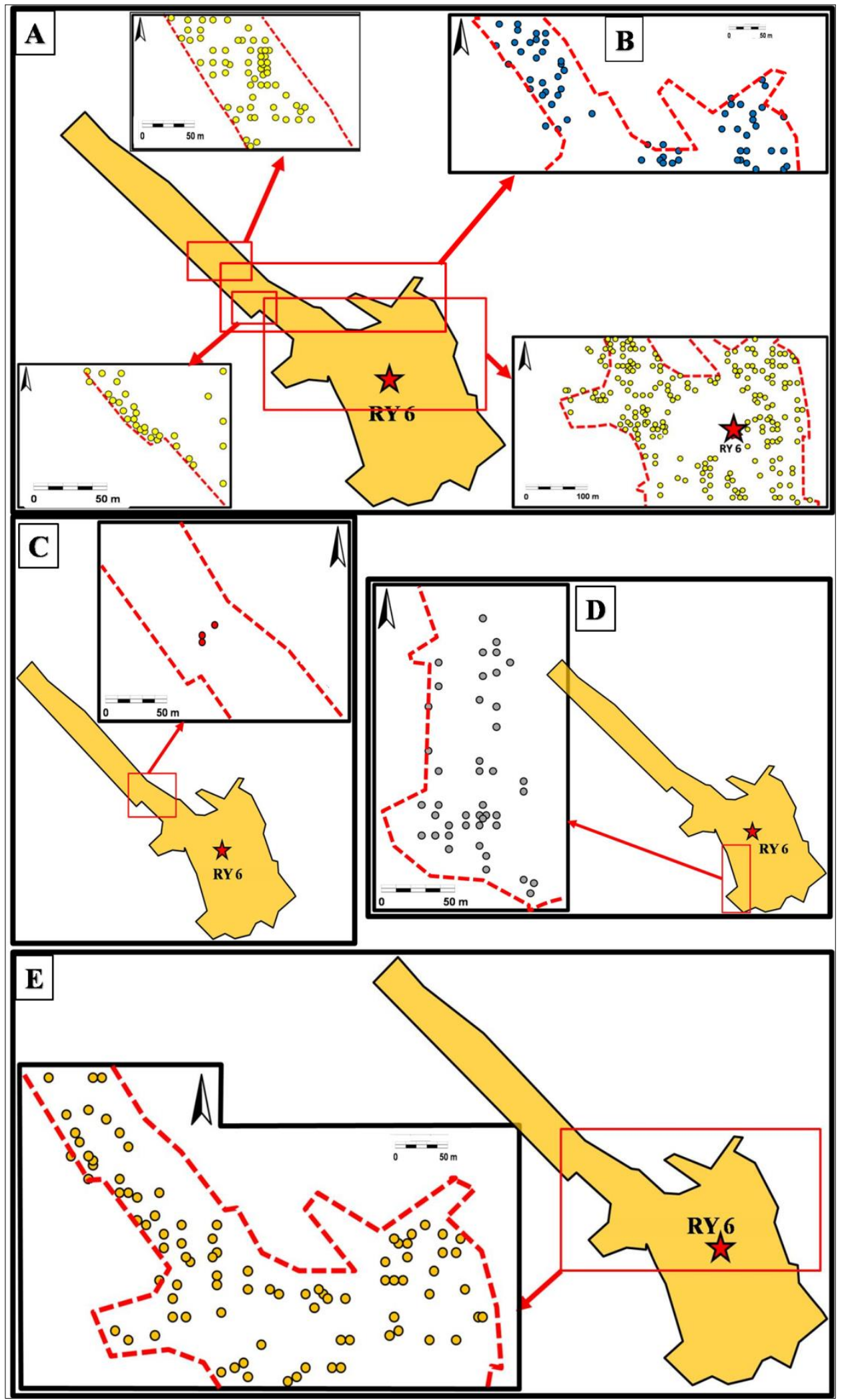

Figure 4. Location of objects.

Objects dated to: the Early Iron Age (A), the Roman period (B),

the Early Middle Ages (C), the Late Middle Ages (D), the Modern period (E) 


\section{CONCLUSIONS}

Not found in the site permanent or long-term settlement. The site should be considered as group of rather short-lived camps. The most numerous traces of Lusatian culture are not a single phase, but rather multiple returns to the same area AT short intervals (the homogeneous ceramics). Probably the presence of human groups was related to some economic activity not related to the agriculture (cattle grazing?) and the presence of water reservoirs motivated them to choose this place. However this activity led to soil erosion and formation of deluvia cover (colluvium) in endorheic depression.

\section{REFERENCES}

[1] Galon R. Pojezierze Pomorskie i przyległe wysoczyzny jeziorne [in:] R. Galon (ed.) Geomorfologia Polski, tom 2. PWN, Warszawa, pp 129-156, 1972.

[2] Kondracki J. Geografia regionalna Polski, PWN, Warszawa, 2002.

[3] Tylmann K., \& Wysota W. Geneza i transformacja rzeźby morenowej w północno-zachodniej części Garbu Lubawskiego (Polska północna, Przegląd Geologiczny vol. 59 (11), pp 739-750, 2011.

[4] Kalicki T., Chrabąszcz M., Maciszewski I. \& Przepióra P. Geoarchaeological studies near Rychnowo in the Upper Drwęca catchment area, 23. Kvarter, Brno, pp 54-55, 2017.

[5] Kalicki T., Chrabąszcz M., Maciszewski I. \& Przepióra P. Impact of the Lusatian culture on landscapes of the last glaciation: a case study from the upper Drwęca river basin (N Poland), Abstracts, Programme and General Information, $14^{\text {th }}$ Conference of Environmental Archaeology 2018 „Humans and environmental sustainability: Lessons from the past ecosystems of Europe and Northern Africa", Modena, pp 12-13, 2018.

[6] Kalicki T., Chrabąszcz M., Maciszewski I. \& Przepióra P. Prehistoryczna transformacja rzeźby na stanowisku archeologicznym Rychnowo V w zlewni górnej Drwęcy, Acta Geographica Lodziensia vol. 107, pp 11-23, 2018.

[7] Folk R.L. \& Ward W.C. Brazos River bar: A study in the significance of grain size parameters, Journal of Sedimentary Petrology, vol. 27, pp 3-26, 1957.

[8] Smolska E. Denudacja antropogeniczna - zapis w rzeźbie i osadach na wybranych przykładach z obszaru Pojezierza Suwalskiego, [in:] Szwarczewski P. \& Smolska E. (ed.) Zapis działalności człowieka w środowisku przyrodniczym, Warszawa-Łomża, vol. 1, pp 113-119, 2002.

[9] Kalicki T. Zapis zmian klimatu oraz działalności człowieka i ich rola w holoceńskiej ewolucji dolin środkowoeuropejskich, Prace Geograficzne IGiPZ PAN, vol. 204, 2006.

[10] Karczewski M., Smolska E. \& Kalicki T. (ed.) Środowisko przyrodnicze, gospodarka, osadnictwo i kultura symboliczna w V w. p.n.e.-VII w. n.e. w dorzeczach Odry i Wisły, Białystok-Warszawa-Kielce, 2014.

[11] Wawrusiewicz A., Kalicki T., Przeździecki M., Frączek M. \& Manasterski D. GrądyWoniecko, Ostatni łowcy-zbieracze znad środkowej Narwi, Białystok, 2017. 